\title{
The Study Urban Context, the Development and Promotion of Industrial Tourism: Example of the Nord-Pas de Calais in France
}

\author{
Szymon Opania \\ Department of Urban and Spatial Planning, Faculty of Architecture, Silesian University of Technology, Gliwice 44-100, Poland
}

\begin{abstract}
The ongoing processes of spatial transformation of post-industrial regions attract people's attention, and they show new possibilities of development but they are also related with new challenges. A deep analysis of known patterns must be an important lesson as, first of all, we observe transformation of other regions, which gives rise to a question about the possibility of using positive model solutions in other urban contexts. Moreover, in every action contributing to the development of a region with traditions, we should use every potential, understood as accumulated energy and closed in facilities, individuals and their mutual relations. The article is divided into five parts: (1) a short history of Nord-Pas de Calais; (2) a significant introduction to history and spatial issues; (3) a description of corrective measures undertaken on the basis of, e.g., an urban analysis from the moment of taking a decision on ceasing coal mine extraction until today; (4) a description of "a concept for the region"; (5) conclusions_-including a catalogue of actions, prepared by the author, where an important aspect will be the use of elements of spatial values and spatial identity of regions in the process of planning spatial, social and economic transformation. In the article, the results of studies conducted in years 2010-2015, based on statistical data analysis, strategic documents analysis and an on-site visit are presented.
\end{abstract}

Key words: Regional development, regional projects, region transformation, spatial values.

\section{Nord-Pas de Calais-Brief Characteristics of the Region}

Nord-Pas de Calais is a region in the far north of France, adjacent to the La Manche Channel. It has a population of about 4 million people and the area of over 12 thousand square kilometers. Its capital is Lille, with about 225 thousand inhabitants, being at the same time the capital of the Nord department. The capital of the other department-Pas de Calais, is Arras. The region is divided into 13 arrondissements and 156 cantons, the main towns, apart from Lille, are: Roubaix, Tourcoing, Calais, Dunkerque, Villeneuve-d'Ascq, Boulogne-sur-Mer, Arras and Valenciennes, where, in total, almost $20 \%$ of the region's population live.

Corresponding author: Szymon Opania, associate professor, architect, research fields: architecture, urban design, spatial planning, city management, sustainable development, revitalization, environmental protection in spatial planning, evaluation of the quality of spatial structures and processes of development of the Upper Silesia Agglomeration.
The industrial nature of the Nord-Pas de Calais region is due to Bassin Miniers, which is related with the mining industry: extraction and processing. The area on the surface: $1,800 \mathrm{~km}^{2}$ inhabited by $1,260,000$ people, which gives it population density of $700 \mathrm{M} / \mathrm{km}^{2}$ (Fig. 1). All in all, $30 \%$ of the population live on $15 \%$ of the area, and that is why the area differs from its surroundings and it is crucial for the region's image.

At the same time, the stages of the basin's development had influence on the spatial structure of the region. The remains of mining operations were: 150 mine shafts, 220 hoist towers, 300 mine waste dumps, 700 housing estates for miners, 300 social facilities (hospitals, schools and nurseries), 65 religious buildings, i.e., churches and chapels and $345 \mathrm{~km}$ of railway lines [1].

The distribution of people in the region's structure, presented in Fig. 2, is related with the industrial nature of the region, concentrated in Bassin Miniers, which has direct impact upon population density in the region. 


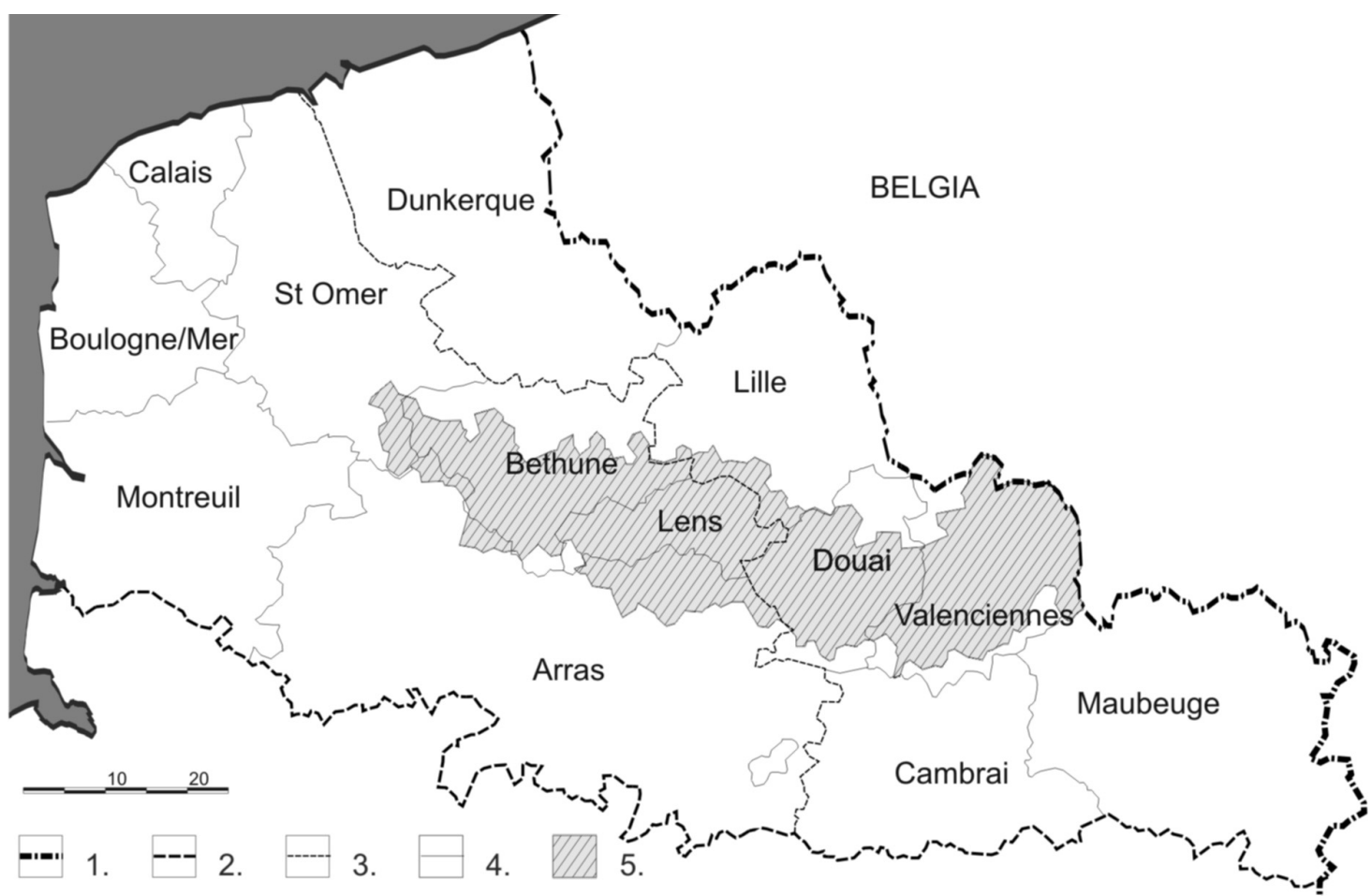

Fig. 1 The mining basin in Nord-Pas de Calais (1-national border; 2-Nord-Pas de Calais regional border; 3 - department borders; 4, 5-border and coal basin).

Source: the author's own work.

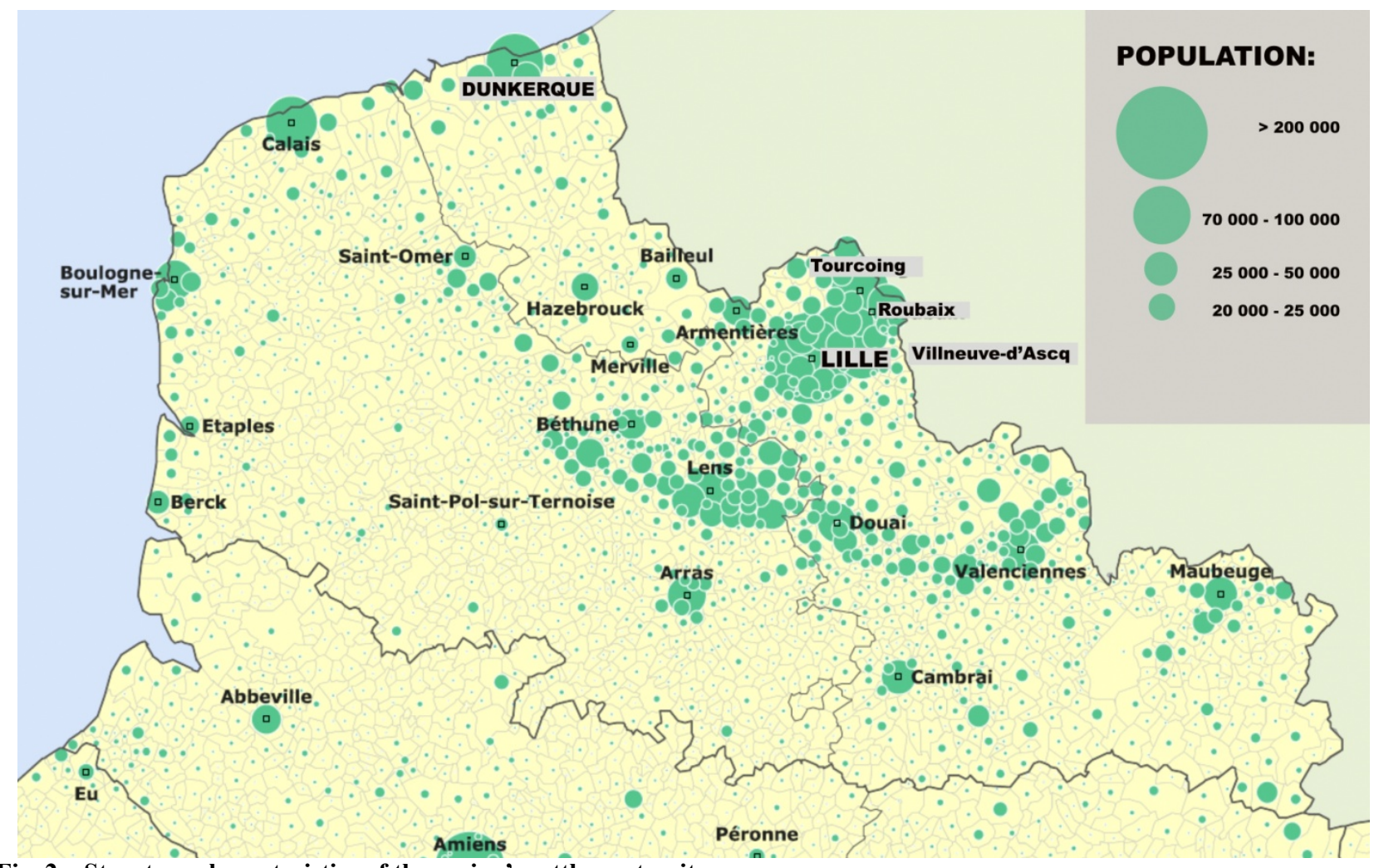

Fig. 2 Structure characteristics of the region's settlement units.

Source: the author's own work based on INSÉÉ [2]. 


\section{The History of the Region's Transformations}

The character of the region has its origin in 1720 when coal mining started in Fresnes-sur-Escaut, near Valenciennes. These operations were particularly developed at the end of the 19th and the beginning of the 20th century. Before 1950, the Nord-Pas de Calais Basin produced more than half of coal produced in France and it played a strategic part in the country's reconstruction after World War II. Until the end of the 1970 s, it was one of the most important industrial regions in France.

In 1960, the government of Charles de Gaulle made a strategic decision concerning changes in the energy policy of France and giving up energy based on coal in favor of energy generated from crude oil and development of nuclear energy. Hard coal extraction decreased from about 60 million tons in the 1960s to 8.7 million tons in 1996.

The end of mining was a process that lasted 30 years. Stopping coal extraction resulted in changes in many sectors of industry: steel, textile and it created the problem of unemployment. It was also related with degradation of existing land development and infrastructure- both social and technical [3].

Such a history of development is typical of many industrial hubs, such as: the Midlands in England, the Ruhr region in Germany, the Ostravsko-Karvinská region in the Czech Republic, the Donets Basin in Ukraine and the Upper-Silesian conurbation in Poland. It always left a characteristic landscape behind, degraded environment and deep social problems. The results of all this are all kinds of threats to the regions' development processes embedded in: economic stagnation-related with the collapse of industrial monoculture, increasing unemployment with all accompanying negative social phenomena and deep environment degradation.

\section{Corrective Measures}

Changes leading to transformation started at the beginning of the 1970s and they are still ongoing.

In the 1970s, the decision on the beginning of reclamation of 10,000 ha of post-industrial land was made - it was to be used for new industrial and economic activities. This decision was based on a conviction of a negative image of the area and its low attractiveness to investors, caused by more than 270 year of mining operations.

The beginning of the 1980s was a time where problems in many spheres were revealed. They were related with cessation of mining and they imposed the necessity of undertaking multidirectional remedial measures aiming at solving the key problems:

- in the social sphere - characterized by significant depopulation of the society and aging as well as diagnosed gaps in the health care system and schooling level, it forced preventive actions against these symptoms that were accompanied by efforts to change people's mentality;

- in the economic sphere - the main objective of the authorities was to facilitate industrial diversification and to favor instillation of new activities. In place of traditional sectors, new ones occurred, represented by facilities producing means of transport, subassemblies and electronic products, chemical coloring agents, synthetic fibers and medications. Petrochemical, printing and food industries also developed;

- in the spatial sphere - there was a strong focus on transformation of regions in order to regain the urban tissue and to reclassify the natural environment.

Due to European Union funds, the state and region authorities could use, under an agreement, new resources for post-industrial land reclamation. At the same time, actions supporting the economic sector were carried out with new dynamics, and so were renovations aimed at using the existing buildings, 
including efforts to preserve hoist towers, which was part of the policy of promoting remembrance of the times of mining operations. The biggest mining museum in France, Centre Historique Minier in Lewarde, dates back to those days. While the most valuable industrial facilities were undergoing renovation, miner housing estates were also being repaired and their standard was being increased to match that of the newly built estates. One of the elements of activities aiming at restoration was the creation of a regional strategy of tourism and leisure development, whose key objectives were to strengthen the image of the Nord-Pas de Calais region and to impart real economic dimension to tourism and recreation [4]. In years 1984 1988, as part of the experimental State and Region Development Treaty CPÉR (Contrats de Plan État-Région), the areas started being cleaned in accordance with the "reuse of post-industrial areas" programme according to two procedures:

(1) return to the "zero state" (demolition, ground works) and securing the buildings (mainly against weather conditions);

(2) protective actions (planting) cost $<0.8 € / \mathrm{m}^{2}$.

In years 1989-1993, CPÉR continued with a particular focus on those areas of industrial basins which suffered the most due to transformation and areas where this policy was integrated with a holistic approach to spatial planning and development strategies. Three types of post-industrial areas were given priority:

(1) large post-industrial areas that local capacity could not deal with;

(2) post-industrial areas that could be used for large projects;

(3) post-industrial areas whose reuse would promote active life of the local community.

In years 1994 1999, CPÉR implemented and reinforced the policy of reuse of post-industrial areas (about 5,000 ha). The aim of the policy was to improve the condition of the environment, to preserve post-industrial terrains with the perspective of their further development in the future as a significant technical culture heritage and to stimulate economic and social development through rational regional planning.

We must emphasize here that in years 1970 2000, coal mines' administration decided to demolish most of the mining facilities. They were allowed to do it under French law, including demolition of coal mine buildings, as they terminated working there, without paying attention to any historical aspects or cultural heritage protection. Building complexes of only four coal mines survived until today: Lewarde, Loos-en-Gochelle, Oignes and Wallers-Arenberg.

In the period from 2000 to 2006, previous activities were continued, though by then mass reclamation of post-industrial lands had finished and thus their area decreased by about 5,000 ha as compared to the initial 10,000 ha.

\section{A Concept for the Region}

Since 2000, CPÉR has been focusing on conducting a policy of post-industrial area restoration, but only by supporting large projects that would be of importance not only locally but mainly regionally. This restoration is to be a reason for development, while these actions were to be integrated by use of a planning process and development policy.

Some of issues that became priorities were: creation of a Regional Green Strip and reduction of the surface of polluted land and soil. In that period, 1,200 ha were reclaimed, including areas with a large surface or/and of symbolic significance (areas related with remembrance of the past and separate hoist towers). Urban areas, scattered across post-industrial lands and the planned Regional Green Strip were identified as elements of cultural heritage of the region. For that purpose, in 2000, Mission Bassin Minier was appointed and its task was to support local and regional authorities, e.g., in restoration of degraded urban areas, promotion of cultural heritage and change of the 
region's image [5]. The first tasks it performed included preparation of an inventory and assessment of facilities, which now became the basis for decisions on demolition and restoration of the land to the "zero state". As a result of this so called general inventory in 2008, 1,114 facilities were described, which constituted $65 \%$ of all the facilities constructed from 1720 to 1990 . The inventory covered: output shafts, hoist towers, mine waste dumps, miner housing estates, equipment of a mine rescuer association, religious buildings (churches and chapels), social facilities (hospitals, schools, nurseries) and railway embankments. A small part of these facilities and terrains was bought by municipalities, leaving them, according to the inhabitants' will, as "witnesses of the history", which were mainly hoist towers and individual dumps (Figs. 3 and 4).

The revitalization policy, aiming at revival of post-mining, small towns and the emphasis put on preservation of cultural heritage became important elements of Mission Bassin Minier's policy. As a result of this way of thinking in 2002, attempts were made to enter the Nord-Pas de Calais mining basin in the UNESCO (United Nations Educational, Scientific, and Cultural Organization) World Heritage List in the category of "transformed cultural landscape". The category allows to present the basin not as a collection of areas and monuments, but as an organic and coherent whole where history is united with remembrance, nature with buildings, technical infrastructure with residential (Fig. 5). It was a spectacular step showing a region which is well-situated in the structure of European connections and which is developing. Attempts to enter the basin into the UNESCO World Heritage List were the consequence of a long-lasting process of handling the outcome of mining operations as well as a concept for future development. The grounds for being entered in the list are, in particular, universal cultural values. Criteria: significant impact of values in a specified period or a specified cultural circle-in terms of architecture or technology development, art of historical value or spatial planning of towns and/or shaping the landscape. $25 \%$ of all the existing engineering facilities, $15 \%$ of existing railway lines with embankments and such elements that were covered by the general inventory were selected for the list.

The objectives of this action were both promotion and protection.

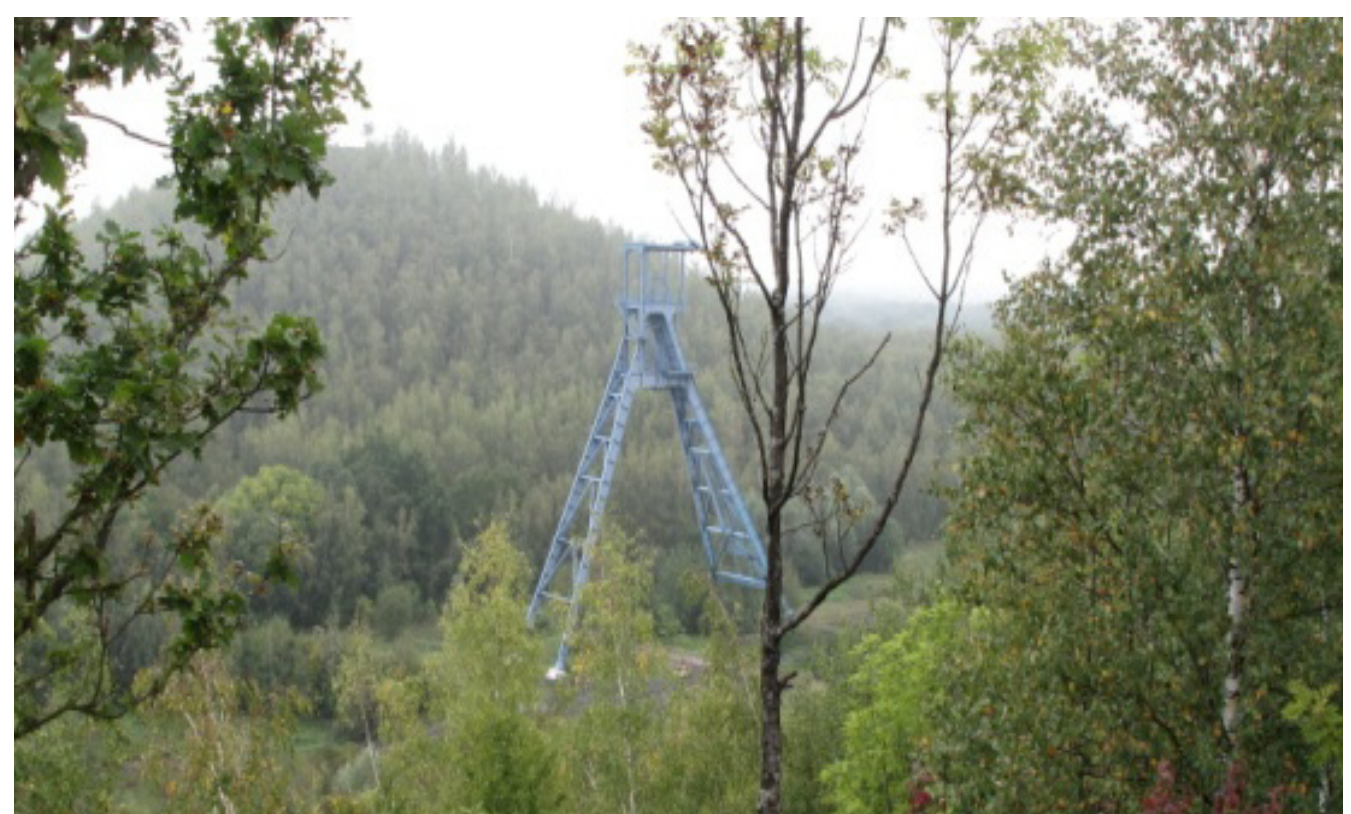

Fig. 3 The tower of an output shaft of the Maurice Sabatier coal mine in Thiers, left between two conical dumps. Source: photograph by the author in 2010 . 


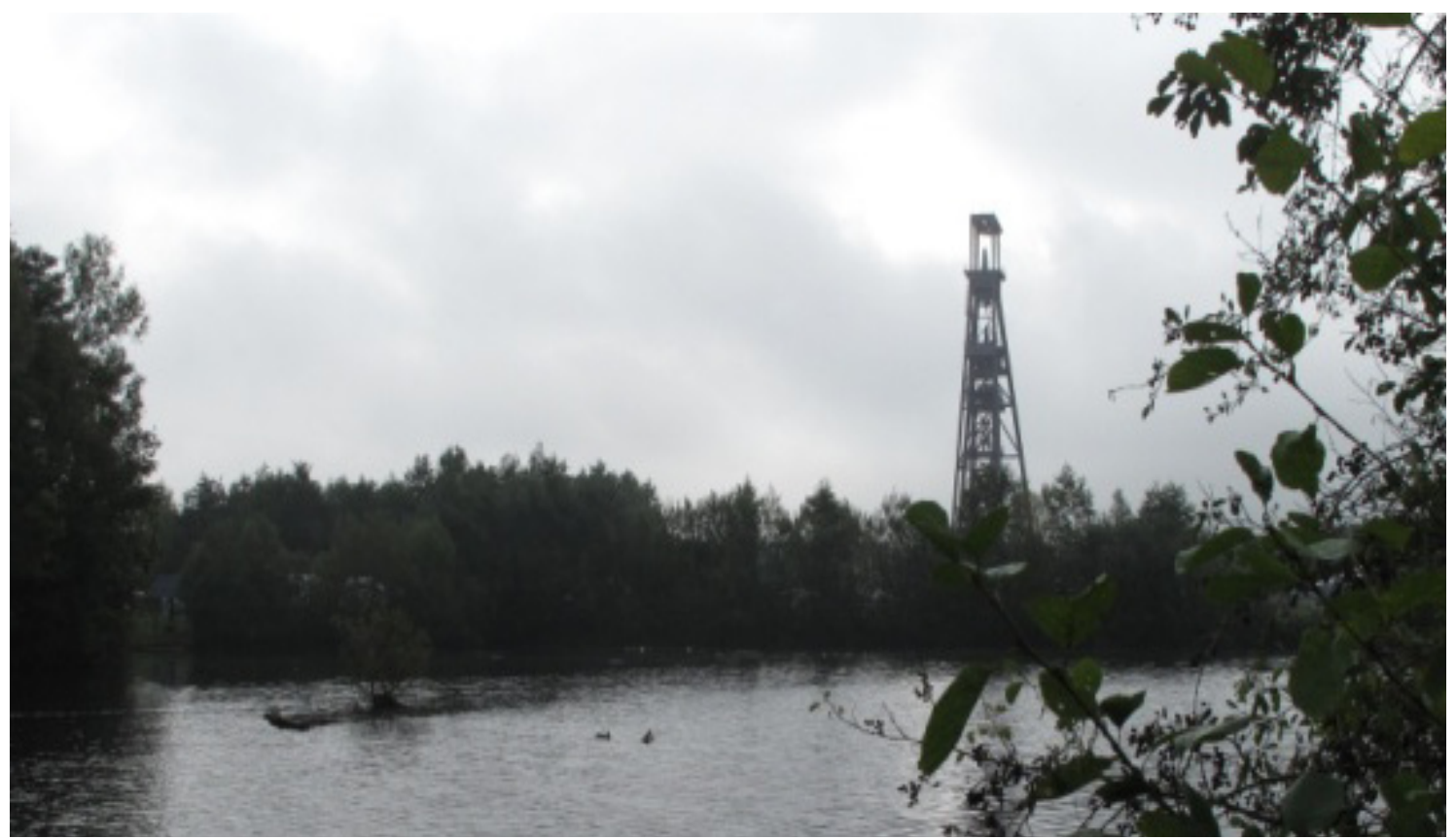

Fig. 4 Condé-sur-Lescaut—a hoist tower in the naturalized landscape of Chabaud-Latour.

Source: photograph by the author in 2010 .

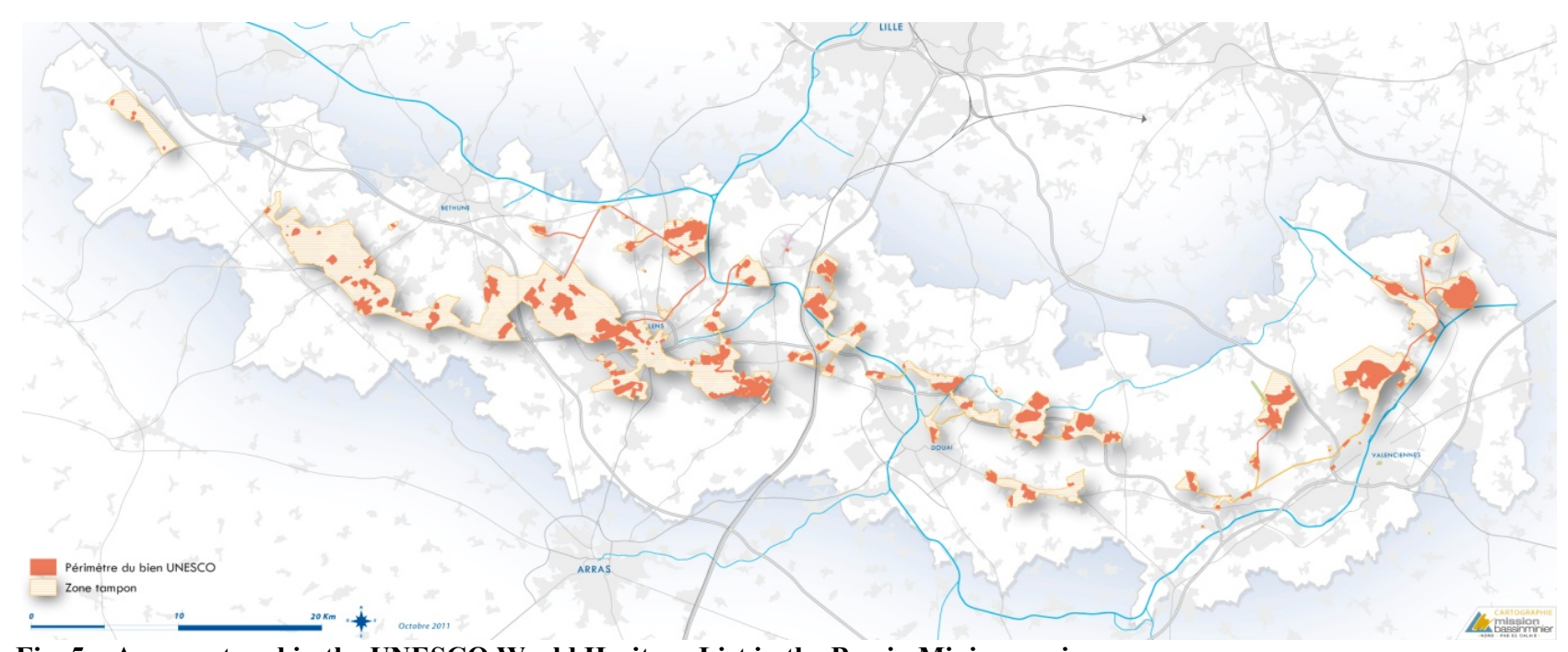

Fig. 5 Areas entered in the UNESCO World Heritage List in the Bassin Miniers region.

Source: Ref. [6].

Then implementation of other projects started. The projects were:

(1) to attract new investors, which include:

- construction of Centre Historique Minier in 1982 in Lewarde, including the Mining Museum and the centre of regional resources. Being located in historical facilities of the Delloye shaft, it offers a broad programme related with the functioning of the museum. It is the centre of activity of the local community which uses lecture rooms, the restaurant and which organizes all kinds of special events there, also cultural and sports events as well as bicycle tours;

- expansion of the Louvre Museum by a new seat in Lens, being the result of political, economic and social planning, which resulted in the selection of Lens for the new seat. The location in the area of former shaft " 9 " in the vicinity of the highest two conical dumps (approx. $186 \mathrm{~m})$ in Loos-en-Gohelle was to combine 
technological and cultural achievements in that place. The facility was opened in 2012 and since then it has been visited by 700 thousand people, with the perspective of 500 thousand visitors per year, which is 1,300 persons per day. The author of the design - the SANAA studio-was selected in an international competition with well-known architects as participants, e.g., Steven Holl, Rudy Ricciotti or Zaha Hadid, which was an important element of urban marketing.

- adaptation of the surroundings and buildings of 9/9 bis shafts in Oignies (10 thousand inhabitants) to a centre combining technological and innovative activities of the third sector, related with logistics, cultural activities-music and cultural heritage of mining as well as business tourism. The main point of adaptation is Métaphone, a modern facility, a chime, which gave the place its modern image. Reclassification of the facility will be mainly based on the topic of music and sound, with reference not only to the tradition of miner orchestras - still active in the region-but also with reference to all kinds of coal mine sounds which will be replayed for tourists in a multimedia performance;

- adaptation of shaft 11-19 in Loos-en-Gohelle for a culture centre with a national stage and a special economic zone dedicated for sustainable development, a didactic centre for eco-development, resource centre and CPIE-Chaîne des terrils — a trail of conical mining waste dumps which are typical for the region;

- arrangement of Wallers-Arenberg shaft facilities in Hainaut which will combine technological and innovative activities of the third sector, related with cultural activities connected with digital technologies and film production.

Due to investments in the so called "big projects" Nord-Pas de Calais became the second region in France, after the Paris arrondissement, in terms of size of investment in culture;

(2) to create a regional strategy of tourism and leisure development:

Its objectives were to strengthen the image of the
Nord-Pas de Calais region and to impart real economic dimension to tourism and recreation. In order to achieve them a programme of tourism development was elaborated - it would provide specific solutions and undertakings aiming at achieving success of the whole region. Some elements of the strategy included defining the links between entities interested in the development of tourism in the region. Actions aiming at improvement of quality of tourism products and region development, e.g., services and goods, tourist traffic management, marketing, information, promotion and monitoring as well as determining the needs of the market, social and economic phenomena as well as resources and values of the region;

(3) to impart real economic dimension to tourism and recreation:

Some of the projects implemented in this field include:

- a landscape park in the form of lagoons in Harnes, whose task is also to create the town's new image, while it is a biological waste treatment plant. It is situated on post-mine land, in the location of operating shafts "9" of the Harnes coal mine. In 2006, this unique project on a regional scale was awarded first prize at the Landscape Biennial in Barcelona for special "aesthetic and poetic achievements as well as for educational and ecological values and for contribution to the region's transformation";

(4) to improve the condition of natural environment:

Activities in this scope were subordinated to creation of a coherent system of greenery (Fig. 6) including the existing and designed biodiversity areas and they include:

- Des Îles Park on former coking plant site in Drocourt. Its concept assumed very distinctive urban solutions with ideological use of heritage in the form of existing views of dumps and contrasts between the black of the dumps and the green of plants, geometric forms of newly designed islands and naturalized dumps. It will be composed of: a park of islands - the main, representative space of the park, a biological corridor-a 


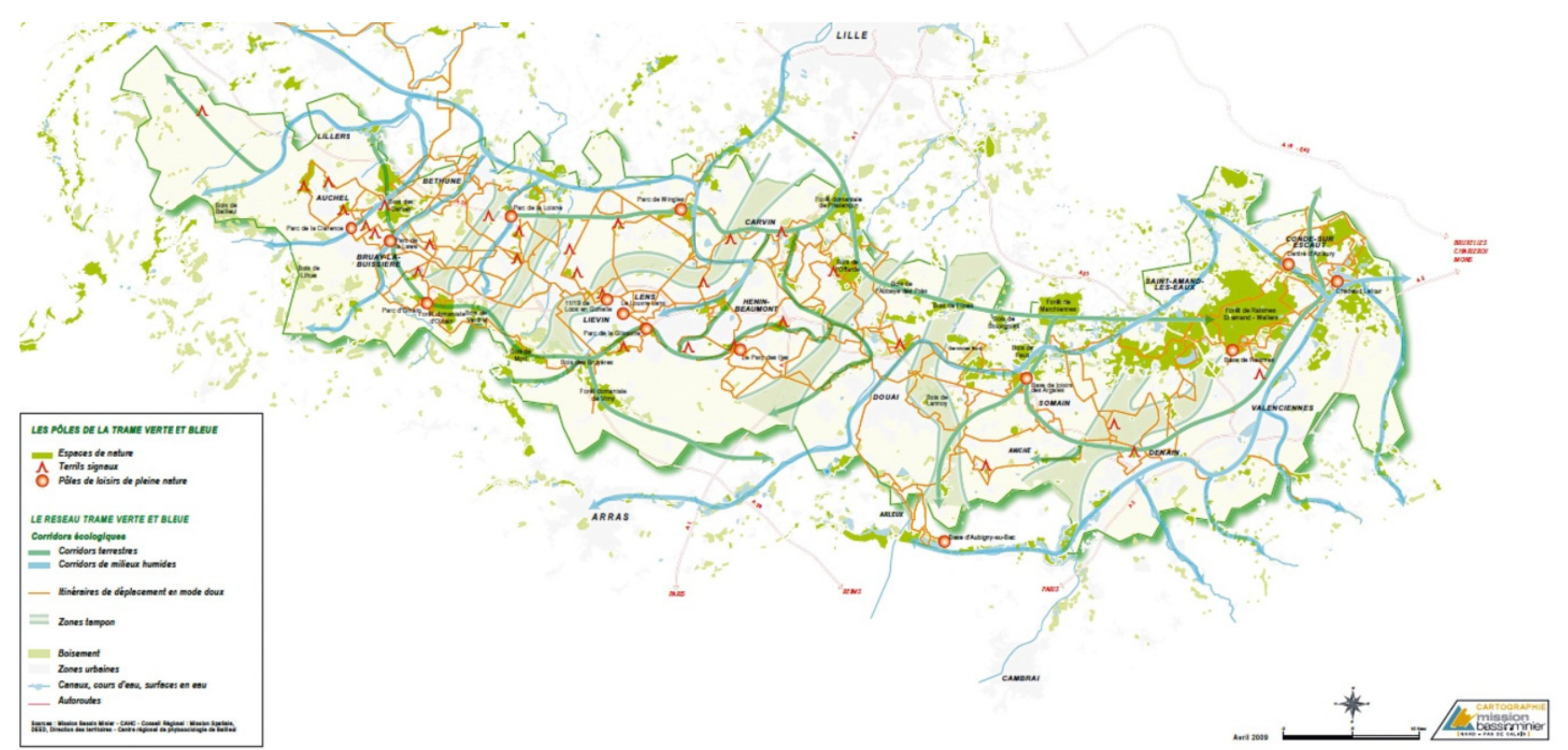

Fig. 6 The regional system of greenery composed of existing forests, nature reserves, wildlife corridors and isolation greenery in the Bassin Miniers region.

Source: Ref. [6].

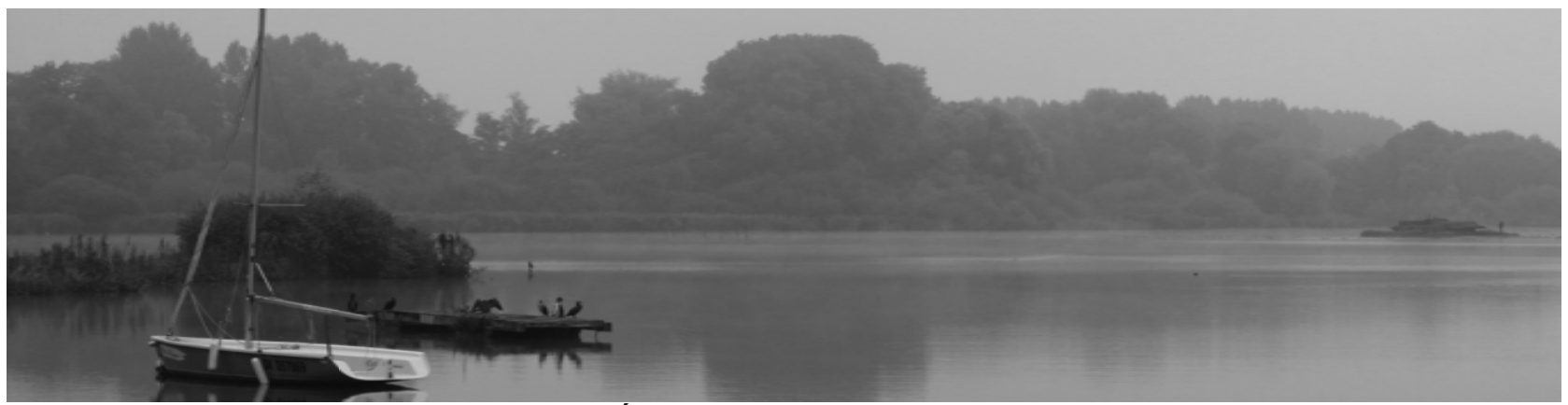

Fig. 7 Reclaimed, waterside recreational area-Étang d'Amaury in the Scarpe-Escaut Regional Park.

Source: photograph by the author.

connector between greenery systems, adventure woods - eco-educational space in the open air and an island of imagination-using modelled heritage of dump number 205;

- Parc Regional Scarpe-Escaut with the d'Amaury (Fig. 7) lake which is one of 45 regional parks and it is the effect of land reclamation carried out in a "natural" way.

\section{Conclusions}

Implementation of a spatial development strategy based on urban context analysis including elements of cultural values for a place and a region has become part of the latest region development tendencies and landscape shaping. They assume that existing values of a place and an area stay a concept for future development with using the UNESCO World Heritage List as universal cultural values. Very often post-industrial area transformation projects, implemented at huge costs and involving enormous structural changes, restore lost values and symbolic meaning to the social space of towns, which has been proven by many European examples. Moreover, implementation of such a sector of industry as tourism provides additional opportunities for development.

\section{References}

[1] Gorgoń, J. 2008. "Od Karbonu do Krajobrazu 


\section{Example of the Nord-Pas de Calais in France}

Postindustrialnego-Zapis Zmian Utrwalony Przez Wizję Artystyczną i Analizę Naukową (From Carbon(iferous) to Post-industrial Landscape-Registration of Changes by Means of Artistic Vision and Scientific Analysis)." In Krajobraz Zbudowany na Węglu, Praca Zbiorowa, edited by Gorgoń, J. Katowice: Instytut Ekologii Terenów Uprzemysłowionych w Katowicach. (in French)

[2] INSÉÉ (Institut National de la Statistique et des Études Économiques). 2015. Paris 2010-2015. INSÉÉ.

[3] Deffrennes, G., and Jarry, S. 2008. Le Bassin Minier du Nord-Pas-de-Calais (The Mining District in Nord-Pas-de-Calais). Rennes: Édition Ouest-France. (in
French)

[4] Dumont, G. 2009. "Entre le Vert et le Noir: La Genèse des Paysages Miniers du Nord-Pas-de-Calais." In Les Paysages de la Mine, un Patrimoine Contesté (Between Green and Black. The genesis of Coal Landscape of Nord-Pas-de-Calais. In "Mining Landscape, contested heritage)?, edited by Debrabant V. Lewarde: Édition du Centre Historique Minier. (in French)

[5] Opania, S. Z. 2012. Tożsamość a Wizerunek. Gliwice: Wydawnictwo Politechniki Śląskiej.

[6] Mission Bassin Minier. 2010. Candidature Journal_Heritage Card. n 9/2010, Oignes. 